\title{
Pluriannual thermal behaviour of low elevation cold talus slopes in western Switzerland
}

\author{
Sébastien Morard, Reynald Delaloye, Fribourg, \\ Christophe Lambiel, Lausanne
}

\section{Introduction}

In the Alps, discontinuous mountain permafrost is currently encountered above about $2400 \mathrm{~m}$ a.s.l., depending on orientation and type of terrain (NöTZLI \& Gruber 2005). Nevertheless, abnormally cold ground conditions indicating possible occurrence of isolated permafrost patches have also been reported at much lower elevations in porous debris accumulation, like talus slopes and sometimes relict rock glaciers (e.g. Morard et al. 2008a; WaKonigG 1996). At these particular sites, found sometimes more than 1000 metres below the regional lower limit of discontinuous permafrost, occurrences of cold air flows $\left(<+5^{\circ} \mathrm{C}\right)$ between the blocks and ground ice in summertime have been recorded despite a mean annual air temperature (MAAT) above $0^{\circ} \mathrm{C}$ (e.g. Delaloye et al. 2003; HaucK \& KNeISEl 2008; SaWAda et al. 2003; TANAKA et al. 1999; WAKONIGG 1996; ZACHARDA et al. 2007). The development of dwarf forests or so-called «Hexenwäldli» (BÄCHLER 1946), boreo-alpine vegetation species and relict ecosystems from the Last Ice Age has also been recorded (e.g. Bertinelli et al. 1993; KöRNER \& Hoch 2006; RUZICKA 1999; ZaCHARDA et al. 2005). Further, the toponymy of these sites often suggests the occurrence of ice: «Eisloch», «Eiskeller», «Toteisboden» (WAKONIGG 1996), «Glacière» (HAUCK \& KNEISEL 2008) and «Ice Valley» (TANAKA et al. 1999). In some cases, geophysical surveys or trenches have pointed out the occurrence of summer ice and sometimes extrazonal permafrost inside the porous debris accumulation (GUDE et al. 2003; HAUcK \& KNEISEL 2008; SAWADA 2008).

Previous research has discussed the possible effect of low solar radiation, the insulating effect of mosses, thermal effect of evaporation in summertime and air exchanges between the ground and the atmosphere for ground overcooling and summer ice at low elevation (Harris \& Pedersen 1998; Wakonigg 1996). Recent studies (Delaloye et al. 2003; Lambiel 2006; SaWAda et al. 2003; WAKONIGG 1996), including the analysis of several tens of sites in Switzerland (e.g. Morard et al. 2008a), highlight the possible role that the reversible air circulation process (the so-called «chimney effect») has in controlling the ground surface temperature (GST) in these talus slopes. The cooling effect of air circulation through porous material is well known. For centuries, it has been used in natural refrigerators (socalled «milkhouses») to preserve food (DE PLANHOL 1995; De Saussure 1796); recently it has been used in embankments to preserve permafrost conditions under transportation infrastructures in regions of high latitude or altitude (e.g. GoERING \& KUMAR 1996).

Reversible air circulation (the «chimney effect»). Variations of both direction and velocity of the airflow in accumulations of loose sediments are primarily controlled by the thermal contrast between the outside and inside (ground) air causing a gradient of driving pressure (Delaloye et al. 2003). The airflow direction reverses seasonally (Fig. 1). During winter, an ascent of relatively warm light air tends to occur in the upper part of the debris accumulation. This leads to a dynamic low (a depression) in the lower part, causing a forced aspiration of cold external air deep inside the ground even through a thick - but porous - snowpack. A gravity discharge of relatively cold dense air occurs during summer in the lowermost part of the debris accumulation, preventing the GST from rising significantly above $0^{\circ} \mathrm{C}$ in this section of the loose sediment accumulation. As a consequence, a diffuse aspiration of external warm air occurs in the upper part of the slope.

The goal of this paper is (1) to present the results of long term GST and atmospheric air evolution monitoring in several cold ventilated talus slopes, (2) to illustrate the effect of meteorological variables (temperature, snow) on the thermal regime in these slopes and (3) to illustrate the effect air circulation can have on creating and/or preserving extrazonal permafrost.

\section{Characteristics of the study sites}

Topo-climatic characteristics from eight porous debris accumulations from western Switzerland are presented in Table 1 and Figure 2. The elevations range from 800 to 1800 metres above sea level. Summer ice and cold air outflows, as well as snowmelt windows in winter - main visual evidences of chimney effect ventilation (MORARD et al. 2008b) -, were observed at all research sites. A dwarf forest is also well developed at the lower part of the Creux-du-Van and Dreveneuse d'en Bas talus slopes, while at other sites vegetation is sparse with a high density of mosses. Gros Chadoua is a talus slope - relict rock glacier complex with several cold windholes located at its front. 

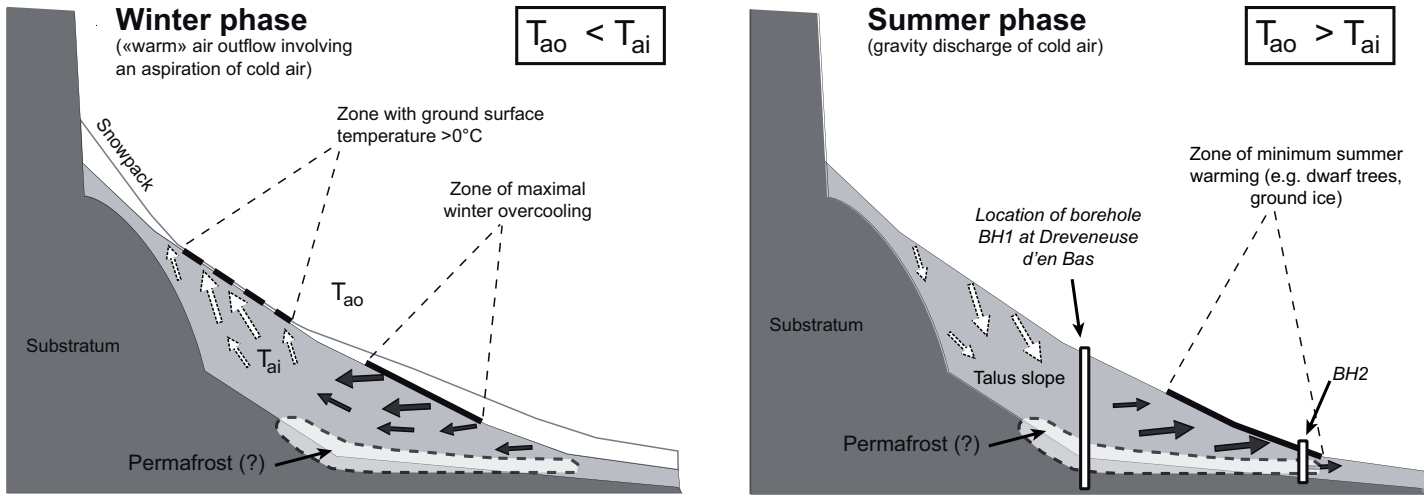

Fig. 1: Models of winter and summer air circulation by chimney effect in a low elevation cold talus slope. The general location of boreholes $\mathrm{BH} 1$ and $\mathrm{BH} 2$ is also indicated. $\mathrm{T}_{\mathrm{ao}}=$ outside air temperature, $\mathrm{T}_{\mathrm{ai}}=$ temperature inside the talus slope

Modèles de circulation d'air par effet de cheminée en hiver et en été dans des éboulis froids de basse altitude. La position des forages $\mathrm{BH} 1$ et $\mathrm{BH} 2$ est aussi indiquée. $T_{a o}=$ température de l'air extérieur, $T_{a i}=$ température de l'air à l'intérieur de l'éboulis

Luftzirkulationsmodelle durch Kamin-Effekt im Winter und im Sommer in unterkühlten Schutthalden auf niedriger Höhe. Die Lage der Bohrungen BH1 und BH2 wird ebenfalls angezeigt. $T_{a o}=$ Temperatur der Außenluft, $T_{a i}$ = Temperatur innerhalb der Schutthalde

Geophysical surveys were also carried out at Creuxdu-Van, Dreveneuse d'en Bas, Dreveneuse du Milieu, Mayens de Bruson and Gros Chadoua. The aim was to determine the thickness of the debris accumulation and the possible occurrence of permafrost at depth. A frozen body is probably to be found at some depth at Creux-du-Van (Delaloye et al. 2003).

\section{Methods}

In addition to the observation of visual evidence, temperatures were measured at the ground surface and in boreholes in order to assess both the long term thermal regime as well as the spatial variability of the ventilation system. Snowcover thickness is also recorded in the Creux-du-Van talus slope.

\subsection{Ground surface temperatures}

Several single-channel dataloggers (UTL-1, Geotest AG) were installed in numerous sites at $10-20 \mathrm{~cm}$ depth recording the GST every two hours. The precision of the measure is about $+/-0.25^{\circ} \mathrm{C}$. All of the devices listed in Figures 3 and 4 were placed in the lower part of the slope where summer ice and cold air outflows occur, except for sensor CV-08. This was placed in the upper part of the slope where warm air outflows are observed in winter (Fig. 2). The external air temperature at $2 \mathrm{~m}$ height and the GST at CV-Soil were recorded with a precision of $+/-0.1^{\circ} \mathrm{C}$ by a multichannel datalogger meteorological station (MADD Technology). Having been intensively studied since 1997, Creux-du-Van provides the longest continuous data series in the world for a cold low elevation talus slope.

The comparison between GST and atmospheric air temperature provides information about both the direction and the intensity of the airflow. When values for both parameters are similar, an aspirating regime may be assumed; when an inverse relationship is recorded, an expelling phase may be assumed at that given moment (LisMONDE 2002). This method has been confirmed by direct measurements of airflow velocity and direction (Morard \& Delaloye 2008; Sone 2005).

\subsection{Borehole temperatures}

In order to document and better understand the ventilation process causing the strong overcooling of the lower part of the debris accumulation, two boreholes were drilled and instruments installed in November 2004 in the Dreveneuse d'en Bas talus slope. Borehole BH1 was situated a few metres above the patch of dwarf trees in the area where air was expected to flow between the lower and the upper part of the slope (Fig. 1 and 2). The porous blocky layer is $11 \mathrm{~m}$ thick at the monitoring point, covering at least $4 \mathrm{~m}$ of much finer loose sediments. Borehole $\mathrm{BH} 2$ is $5 \mathrm{~m}$ deep. It 


\begin{tabular}{|cccccccc|}
\hline $\mathbf{N}^{\circ}$ & Site (Canton) & $\begin{array}{c}\text { Elevation } \\
\text { \& orientation }\end{array}$ & Lithology & Thickness & $\begin{array}{c}\text { MAAT } \\
\mathbf{2 0 0 8 / 0 9}\end{array}$ & $\begin{array}{c}\text { MAGST } \\
\mathbf{2 0 0 8 / 0 9}\end{array}$ & $\begin{array}{c}\text { Thermal } \\
\text { anomaly }\end{array}$ \\
\hline 1 & Creux-du-Van (NE) & $1170-1290, \mathrm{~N}$ & Limestone & $20 \mathrm{~m}$ & $+5.5^{\circ} \mathrm{C}$ & $+0.25^{\circ} \mathrm{C}$ & $-5.25^{\circ} \mathrm{C}$ \\
2 & Dreveneuse d'en Bas (VS) & $1560-1620, \mathrm{E}$ & Limestone & $5-10 \mathrm{~m}$ & $+4.7^{\circ} \mathrm{C}$ & $+0.37^{\circ} \mathrm{C}$ & $-4.33^{\circ} \mathrm{C}$ \\
3 & Dreveneuse du Milieu (VS) & $1600-1800, \mathrm{E}$ & Limestone & $15-20 \mathrm{~m}$ & $+4.3^{\circ} \mathrm{C}$ & $+0.24^{\circ} \mathrm{C}$ & $-4.06^{\circ} \mathrm{C}$ \\
4 & Drudzes (FR) & $1580-1660, \mathrm{~N}$ & Limestone & $?$ & no data & no data & no data \\
5 & Gros Chadoua (FR) & $1580-1750, \mathrm{~N}-\mathrm{E}$ & Limestone & $20 \mathrm{~m}$ & $+4.2^{\circ} \mathrm{C}$ & $-0.59^{\circ} \mathrm{C}$ & $-4.79^{\circ} \mathrm{C}$ \\
6 & Champex (VS) & $1500-1700 . \mathrm{N}-\mathrm{E}$ & Granite (rhyolite) & $?$ & $+5.2^{\circ} \mathrm{C}$ & $-1.25^{\circ} \mathrm{C}$ & $-6.45^{\circ} \mathrm{C}$ \\
7 & Mayens de Bruson (VS) & $1780-1890, \mathrm{~N}-\mathrm{E}$ & Dolomitic limestone & $20 \mathrm{~m}$ & $+3.5^{\circ} \mathrm{C}$ & $-0.75^{\circ} \mathrm{C}$ & $-4.25^{\circ} \mathrm{C}$ \\
8 & Finges (VS) & $770-900, \mathrm{~N}$ & Marble limestone & $?$ & $+9.5^{\circ} \mathrm{C}$ & $+1.15^{\circ} \mathrm{C}$ & $-8.35^{\circ} \mathrm{C}$ \\
\hline
\end{tabular}

Tab. 1: Main characteristics of eight low elevation cold talus slopes in western Switzerland. Sites numbers correspond to markings in Figure 2. Mean annual ground surface temperature (MAGST) was calculated for the (cold) base of the talus slope for the period $1^{\text {st }}$ October 2008-30 ${ }^{\text {th }}$ September 2009.

Caractéristiques principales de huit éboulis froids de Suisse occidentale. Les numéros correspondent à ceux de la carte de la Figure 2. La température moyenne annuelle de la surface du sol (MAGST) est calculée dans la partie basse (froide) des éboulis pour la période allant du $1^{\text {er }}$ octobre 2008 au 30 septembre 2009.

Hauptcharakteristika von acht unterkühlten Schutthalden in der Westschweiz. Die Nummern beziehen sich auf die Karte der Abbildung 2. Die jährliche Durchschnittstemperatur der Erdoberfläche (MAGST) wurde im unteren (kalten) Teil der Schutthalden für die Periode vom 1. Oktober 2008 bis 30. September 2009 berechnet.

was drilled in the lower half of the patch of dwarf trees. The porous blocky superficial material here is only about $4 \mathrm{~m}$ thick.

\subsection{Snowpole}

Snow is a major factor in permafrost studies because it acts as a thermal insulator for the ground (e.g. GoODRICH 1982). In order to study the evolution of the snowpack at low altitude over serveral years and its influence on the thermal regime of a ventilated system, a snow pole was installed at Creux-du-Van in 1998. The device consists of a wooden rod two metres high with temperature sensors (UTL-1, Geotest AG) attached at 0.0, 0.3, 0.6, 1.0, 1.4 and 2 metre intervals. The snow height can thus be reconstructed by comparing the thermal oscillations within the snowpack with those of the atmospheric air (Delaloye 2004; LeWKowicz 2008).

\section{Results}

\subsection{Twelve years of thermal records at Creux-du-Van} During winter, an ascending air circulation regime prevails (Fig. 3). In the upper part of the slope (CV-08), the GST remained above $0^{\circ} \mathrm{C}$, except during a mild weather period in March 2003. Of particular interest is the tendency for GST to gradually decrease from about $+5^{\circ} \mathrm{C}$ at the beginning of November to $+0.5^{\circ} \mathrm{C}$ in March. This trend is remarkably stable during the cold and snowy winters 2005-2006 and 2008-2009. An inverse relationship to outside temperature could also be observed. From mid-April and during the summer, the thermal behaviour is similar to external air temperature regimes, with GST reaching on average $+15^{\circ} \mathrm{C}$ in July.

In the lower part of the slope (CV-Soil), the thermal regime is completely different (Fig. 3). At CV-Soil, GST is at or below freezing point during winter. The thermal regime shows strong variations directly linked to the cold weather. When the snowpack is thick, a delay of a few days can be observed. In January 2009, for example, the GST cooled down despite the onset of thick snowcover of $1.5 \mathrm{~m}$ with temperatures dropping from $0^{\circ} \mathrm{C}$ to $-8^{\circ} \mathrm{C}$ in only a few days. A zero-curtain period may be observed in late winter and spring when meltwater percolates at the base of the snowpack. Ground ice forms at the beginning of this period as well. Generally, the ground remains frozen until around $18^{\text {th }}$ May to $1^{\text {st }}$ June. An exception was the mild winter 2006-2007 when the ground at CV-Soil had already defrosted by $9^{\text {th }}$ May. During summer, the gravity discharge of cold dense air maintains stable cool conditions at CV-Soil between $+2^{\circ}$ to $+6^{\circ} \mathrm{C}$. During this period, there is also a more or less well-established inverse relationship between the GST and the external air temperature.

\subsection{Borehole temperature measurements in Dreveneuse d'en Bas}

During the cold winters of 2004-2005 and 2005-2006, the whole blocky talus slope cooled down strongly and rapidly (Fig. 4). In BH1, a minimal temperature of -8 to 

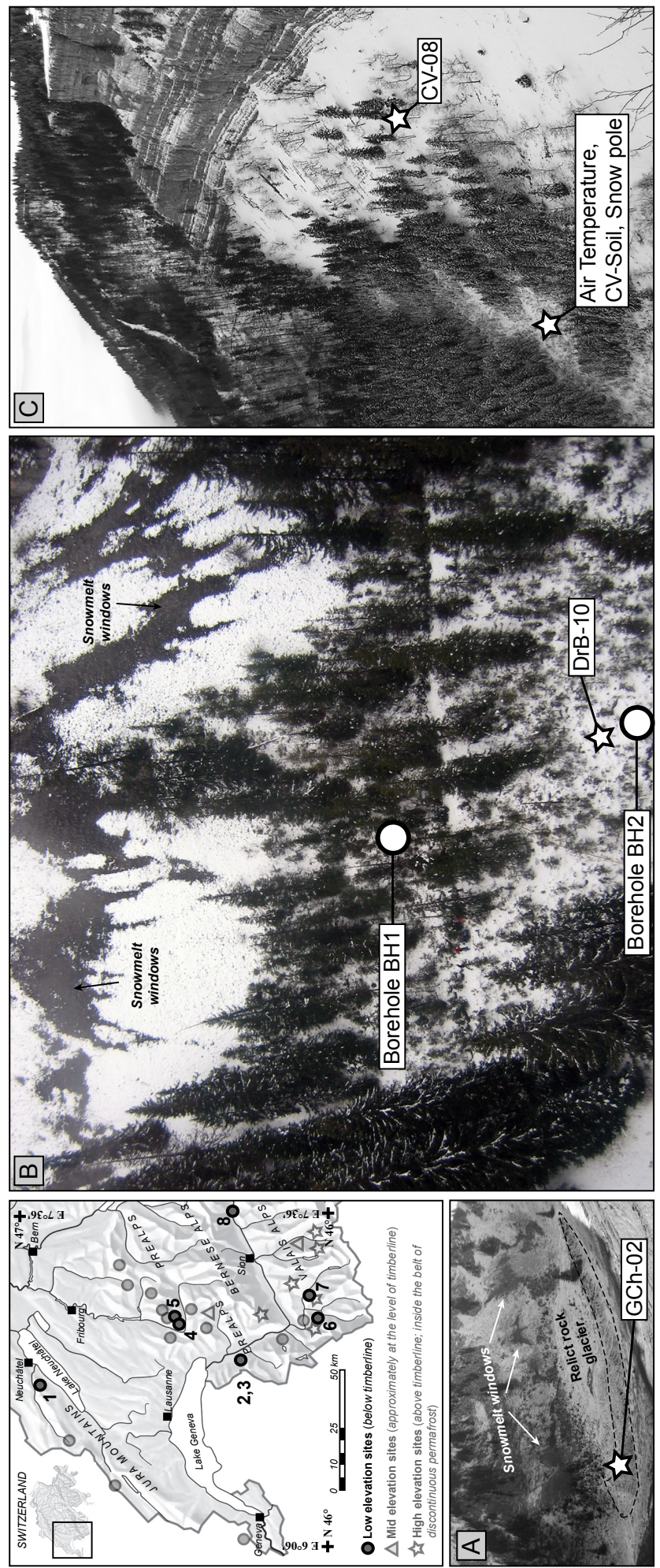

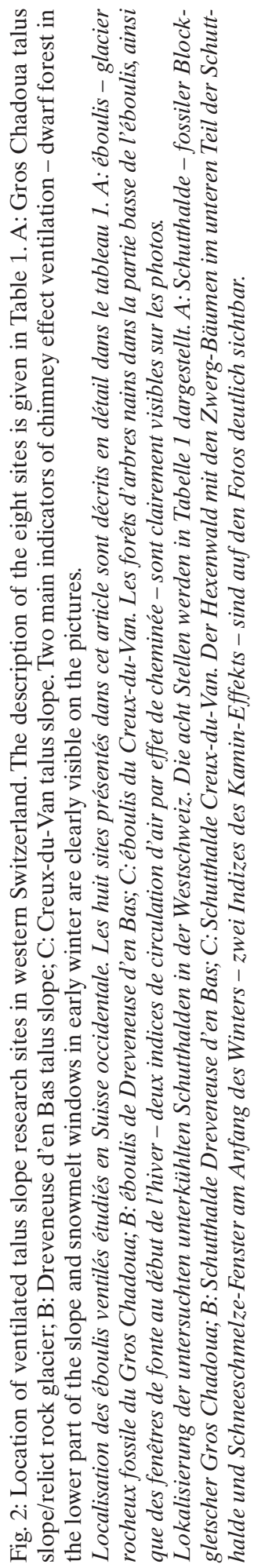




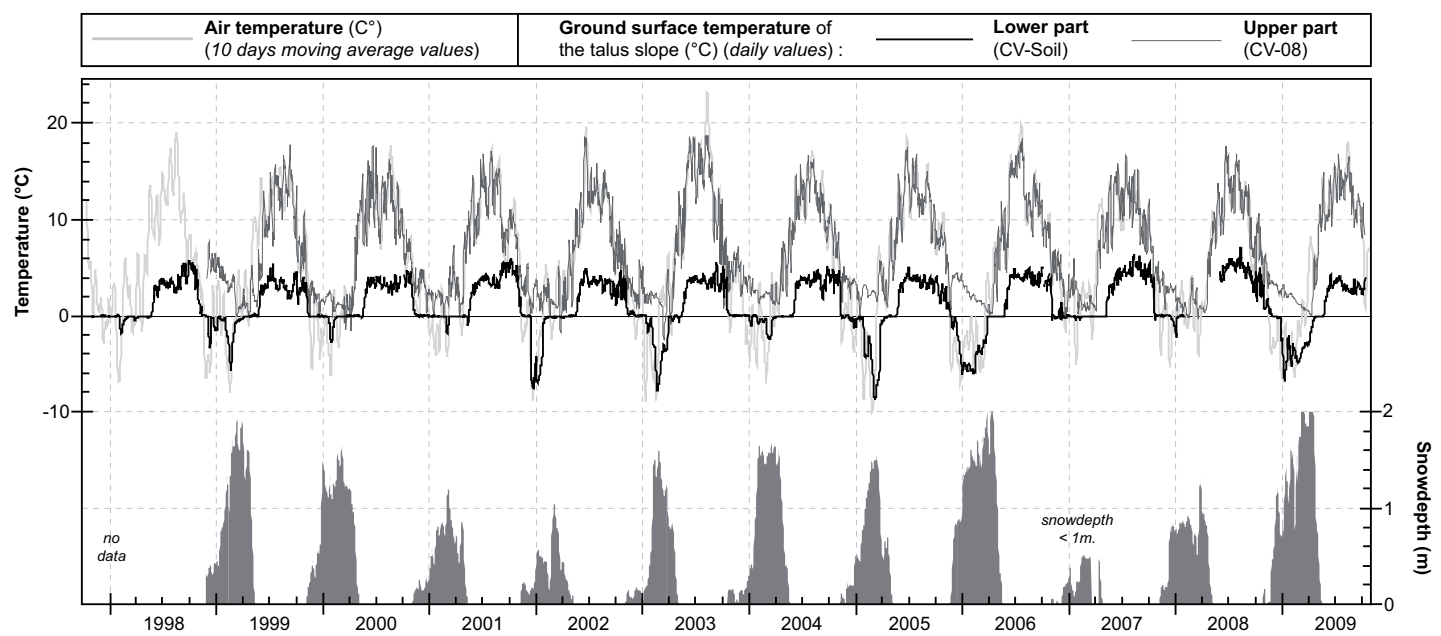

Fig. 3: Daily air and ground surface temperature regimes of the Creux-du-Van talus slope (CV-Soil: lower part of the slope, CV-08: upper part of the slope) and evolution of the snowcover since December 1997

Evolution journalière des températures de l'air et de la surface du sol dans l'éboulis du Creux-du-Van (CV-Soil: partie inférieure de l'éboulis, CV-08: partie supérieure) et évolution du manteau neigeux depuis décembre 1997 Regime der täglichen Aussenluft- und Bodenoberflächentemperaturen in der Schutthalde Creux-du-Van (CV-Soil: unterer Teil der Schutthalde, CV-08: oberer Teil) und Entwicklung der Schneehöhe seit Dezember 1997

$-9^{\circ} \mathrm{C}$ was recorded at a depth of $8.5 \mathrm{~m}$ in January 2006 . In contrast, the ground temperature remained at $0^{\circ} \mathrm{C}$ during the mild winter 2006-2007. During the snowmelt period, the temperature of the whole talus slope generally rose quickly to $0^{\circ} \mathrm{C}$, yet it remained stable and frozen at a depth of $8.5 \mathrm{~m}$ until $6^{\text {th }}$ September in $2005,27^{\text {th }}$ July in 2009 and $16^{\text {th }}$ July in 2008. In contrast, it had already defrosted by $27^{\text {th }}$ April after the mild winter of 2006-2007. During summer, the blocky talus slope warmed gradually from the surface. At $8.5 \mathrm{~m}$ depth, the ground temperature never exceeded $+5^{\circ} \mathrm{C}$.

Beneath the porous talus slope, the ground began to freeze in winter 2004-2005 at a depth of $11.5 \mathrm{~m}$ in BH1 (Fig. 4) and remained frozen for more than a year between the beginning of June 2005 and the end of July 2006. During this period, a thin frozen layer also formed in the porous debris accumulation at $\mathrm{BH} 2$ between a depth of 2-4 $\mathrm{m}$. Since summer 2007, only seasonal freezing has been observed in both boreholes. At $14.5 \mathrm{~m}$ depth in $\mathrm{BH} 1$ and at $4.81 \mathrm{~m}$ in $\mathrm{BH} 2$, the ground temperature remained constantly positive, except for 2 months at BH2 in spring 2006.

\subsection{Long term ground surface and air temperature relationship}

In order to compare the long term thermal regime between different ventilated debris accumulations and the external air temperature, the results of daily GST data from 8 sites (Tab. 1) were averaged to calculate mean annual ground surface temperatures (MAGST). The mean annual air temperature (MAAT) used in Figure 5 was recorded at Creux-du-Van.

The following observations could be made: MAGST at CV-Soil was always colder than MAAT, the offset ranging from -6 to $-3.5^{\circ} \mathrm{C}$. In the upper part of the slope (CV-08), the annual thermal anomaly varies between +0.02 and $+2.3^{\circ} \mathrm{C}$. Two main events stand out in the MAAT-MAGST regime comparison (Fig. 5). The first is the heat wave of summer 2003 which provoked MAGST to increase in the upper part of the slope (CV-08) but did not affect MAGST in the lower part of the slope. Here, a local minimum of $+0.8^{\circ} \mathrm{C}$ was recorded. During the cold winters of 2004-2005 and 2005-2006 CV-Soil temperature decreased to a minimum MAGST of $-0.02^{\circ} \mathrm{C}$.

The second was the sharp increase of MAGST in the lower part of talus slopes between the end of November 2006 and the beginning of October $2007:+1.75^{\circ} \mathrm{C}$ at CV-Soil, $+1.23^{\circ} \mathrm{C}$ at DrB-10, $+1.74^{\circ} \mathrm{C}$ at DrM-21, $+1.77^{\circ} \mathrm{C}$ at Dru- $01,+1.8^{\circ} \mathrm{C}$ at Bru- 03 , and $+2.3^{\circ} \mathrm{C}$ at $\mathrm{Cx}-$ 07 , while CV-08 only increased by $+0.5^{\circ} \mathrm{C}$. A decrease of about 0.5 to $2^{\circ} \mathrm{C}$ was subsequently observed between April and August 2009. 

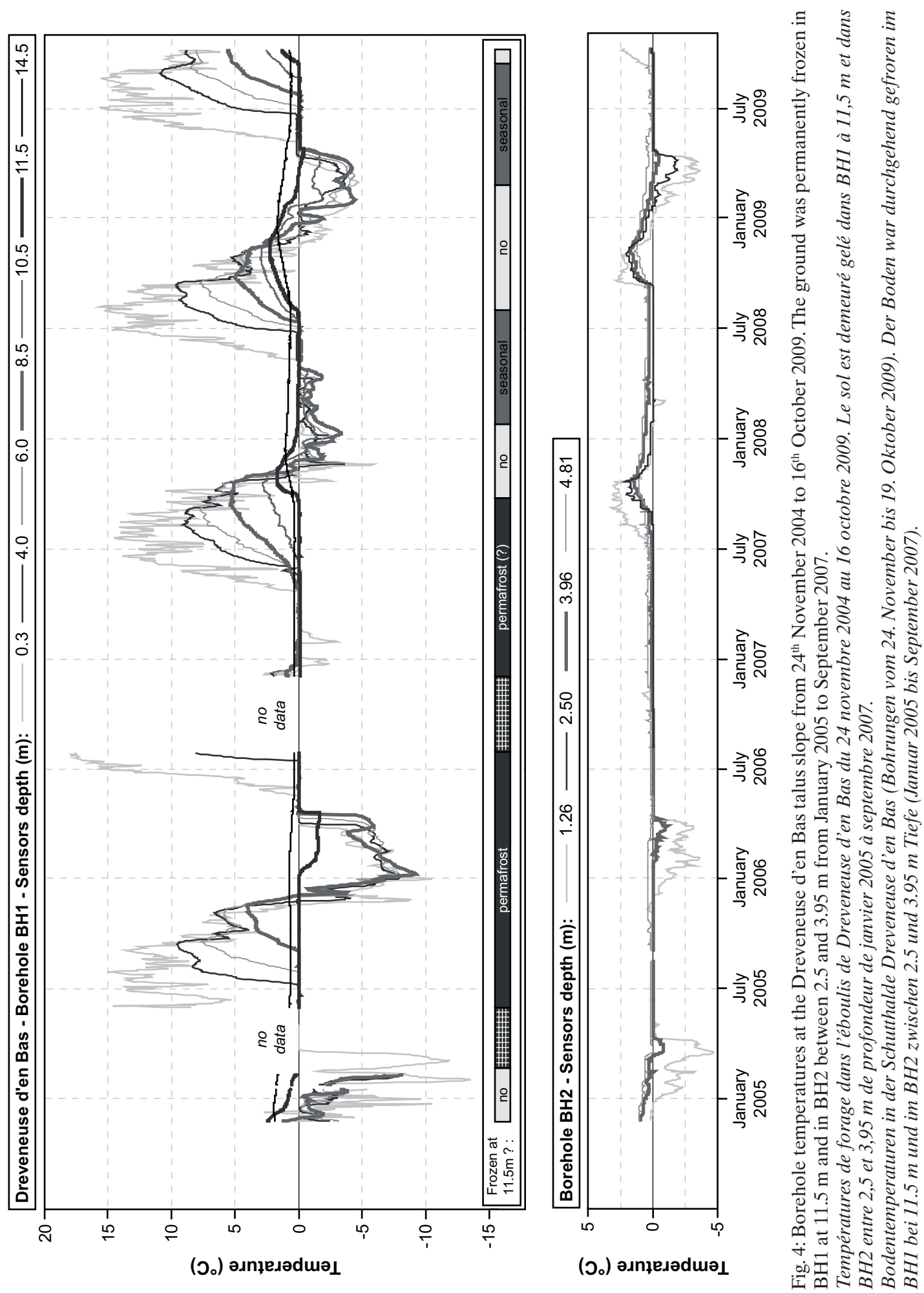


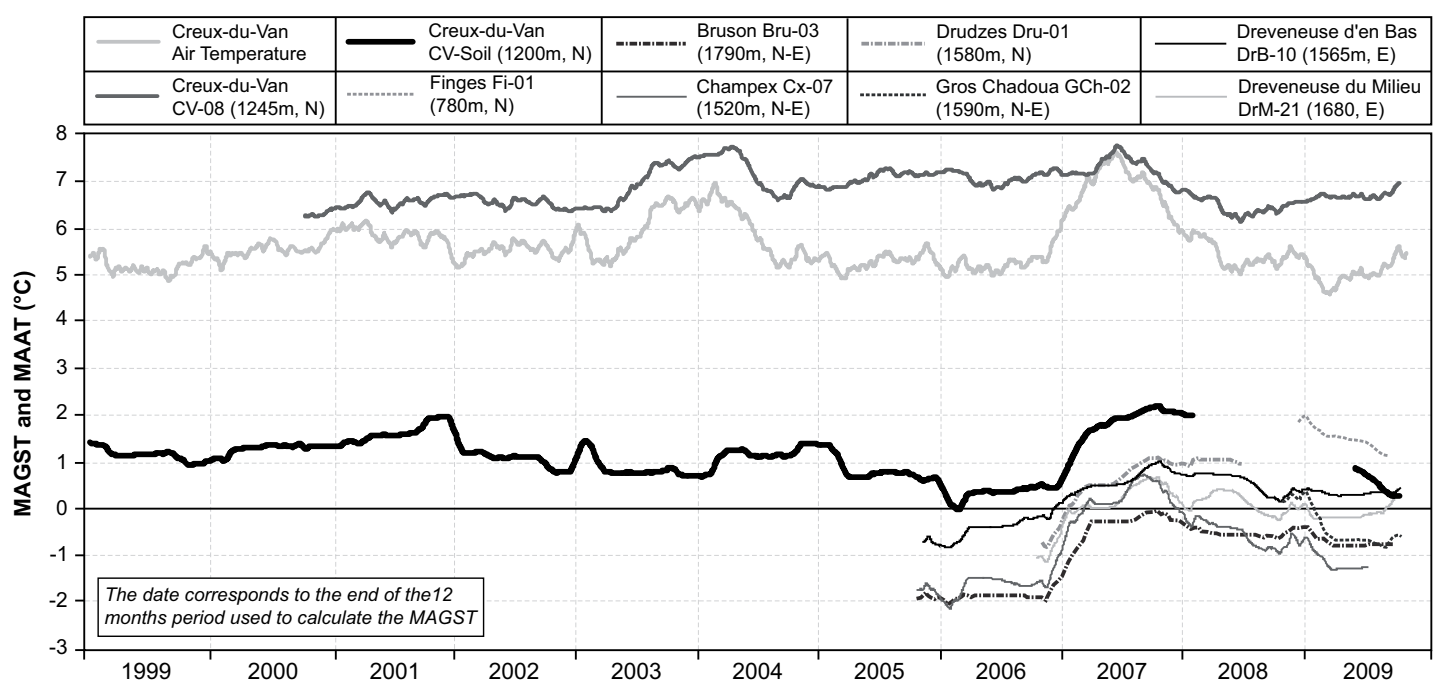

Fig. 5: MAAT at Creux-du-Van (1200 m a.s.l.) and MAGST for different cold talus slopes in western Switzerland. The date corresponds to the mean value of the 12 previous months. MAAT au Creux-du-Van (1200 m s.m.) et MAGST pour différents éboulis froids de l'ouest de la Suisse. La date correspond à la moyenne des 12 mois précédents.

MAAT am Creux-du-Van (1200 m) und MAGST für verschiedene unterkühlte Schutthalden in der Westschweiz. Das Datum entspricht dem Durchschnitt der letzten 12 Monate.

MAGST patterns were on the whole similar in the different ventilated porous debris accumulations investigated, although absolute MAGST values appeared to decrease with altitude. A mean altitudinal gradient of $0.37^{\circ} \mathrm{C} / 100 \mathrm{~m}$ was calculated.

\section{Discussion}

5.1 Continuity and stability of the ventilation process Over the whole of the monitoring period, the Creuxdu-Van talus slope acted as a chimney. In winter, the warmth expelled by the talus slope resulted in a decreasing trend of positive GST in the upper part of the slope. It also caused air to be sucked into the lower part of the talus slope, significantly cooling the ground interior. During summer, ground temperature in the lower part of the slope and in borehole BH1 (Dreveneuse) reflects the gradual draining of the cold reservoir built up during the previous winter. Generally, temperature records presented in this article confirm airflow measurements and observations recorded by other researchers (Morard \& Delaloye 2008; Sone 2005 ) with regards stability of the ventilation process; intensity primarily depends on the thermal gradient between the temperatures in the interior of the talus slope and outside temperatures.
The chimney effect leads to a strong heterogeneous GST regime with a negative thermal anomaly in the lower part of the system and a positive thermal anomaly in the upper part, with transient regimes. MORARD et al. (2008a) proposed a general classification of the different GST regimes. The same annual GST behaviour has also been observed in low elevation talus slopes in Central Europe (Zacharda et al. 2007) and in Japan (SAWADA et al. 2003). Further, the thermal stability and coolness in the lower part of the slope in summertime provide favourable long term abiotic conditions for boreo-alpine vegetation and less-competitive species. ZACHARDA et al. (2005) suggest that these paleorefugia could have remained unchanged since the Pleistocene.

\subsection{Influence of meteorological conditions in the thermal regime evolution}

The long term study of the Creux-du-Van cold talus slope supports discussion of the influence of selected meteorological variables. Warm weather conditions in summer 2003 did not provoke an increase of the GST in the lower part of the slope. The MAGST even slightly dropped. Further, during the mild winter 2006 2007, the ground was not affected by intense cooling, GST and boreholes temperatures remaining at $0^{\circ} \mathrm{C}$. This could be an indication that the ascending air circulation was less efficient due to a weak temperature 


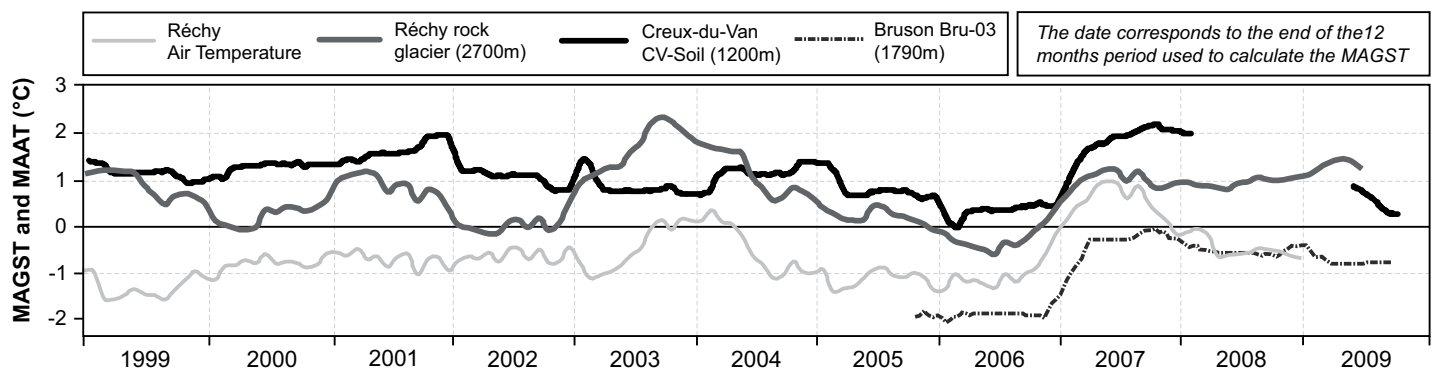

Fig. 6: MAAT at Réchy (2700 m a.s.1.) and MAGST of the active rock glacier at Réchy and in the lower parts of the Creux-du-Van and Bruson ventilated talus slopes. MAGST was $1.5^{\circ} \mathrm{C}$ cooler during summer 2003 at Creuxdu-Van $(1200 \mathrm{~m})$ than at Réchy $(2700 \mathrm{~m})$ !

MAAT à Réchy (2700 $\mathrm{m}$ s.m.) et MAGST du glacier rocheux actif de Réchy et des parties basses des éboulis ventilés du Creux-du-Van et de Bruson. MAGST était 1, $5^{\circ} \mathrm{C}$ plus froid au Creux-du-Van (1200 m) qu'à Réchy (2700 m) durant l'été 2003!

MAAT in Réchy $(2700 \mathrm{~m})$ und MAGST im aktiven Blockgletscher Réchy sowie im unteren Teil der Schutthalden Creux-du-Van und Bruson. MAGST lag im Sommer 2003 am Creux-du-Van $(1200 \mathrm{~m}) 1.5^{\circ} \mathrm{C}$ tiefer als am Réchy $(2700 \mathrm{~m})$ !

gradient between the outside air and ground temperatures. Consequently, the recharge of the cold reservoir was weak, which could also explain the warmer GST recorded during summer 2007 and 2008 at CV-Soil $\left(+1^{\circ} \mathrm{C}\right.$ warmer $)$, and the general MAGST increase recorded in the different investigated sites. On the other hand, during cold winters the ventilation process is highly efficient, leading to a cooling of the interior ground at great depths and thereby creating a large «cold» reservoir. Aspiration of cold air is not hindered by a thick snow pack, the air flowing through the pores of the snow.

Consequently, temperatures during winter, and in particular, the intensity and the duration of cold weather periods, can be marked as the main key variables for thermal balance in a ventilated porous debris accumulation. A similar observation has also been made for ice caves (LUETSCHER 2005). In contrast, due to the inverse relationship between the external air temperature and the GST in the lower part of the slope in summer, and the insignificant role played by snowcover, changes of MAGST in a cold talus slope significantly differ from the MAGST regime observed in conventional permafrost situations (e.g. rock glaciers) at high altitude (Delaloye 2004; NöTZli et al. 2009) (Fig. 6).

\subsection{Possible permafrost in low elevation ventilated talus slope}

The particular thermal regime of ventilated talus slopes is mainly controlled by advective energy fluxes. The «frigories» are supposed to be «stored» by con- duction in the rocky materials and by groundwater freezing (latent heat) during its formation in spring (SAWADA 2008). A part of this energy is also transmitted downwards by conduction in the finer sediments. The dataset of the two boreholes in Dreveneuse d'en Bas allowed to point out the permafrost aggradation, temperate state $\left(0^{\circ} \mathrm{C}\right.$ except between February and April 2006) and particular geometry in the talus slope between 2004 and 2006 (Fig. 1).

The 1-2 m thick permafrost recorded at Dreveneuse d'en Bas is located close to the ground surface inside the blocky material in the lower half of the dwarf trees area, where cold air outflow occurs in summertime, and seems to extend at greater depth at least until the middle of the slope, in the finer sediments just under the talus slope. However, after to the exceptionally mild winter 2006-2007, only seasonal freezing was observed for the following three winters. Due to its rapid formation and disappearance, the frozen ground in Dreveneuse d'en Bas could be associated with short-term permafrost, called «pereletok» by GoRBUNov et al. (2004).

It should be noted, however, that the characteristics of the Dreveneuse d'en Bas permafrost cannot be completely transferred to possible permafrost in other low elevation talus slopes. Morphological distinctive features of the talus slope (e.g. total volume, block size, topography at the base of the talus slope), as discussed in RUZICKA (1999), should also be taken into account because they may influence the size and depth of the cold reservoir. 
While periglacial environments are clearly documented in numerous low elevation talus slopes in Europe (e.g. WAKONIGG 1996), the observation of perennially frozen ground is not as common due to the relative lack of long term direct measurements at depth. In the Klic scree (Czech Republic, MAAT: $6-8^{\circ} \mathrm{C}$ ), permafrost is considered to be highly probable due to seismic measurements which suggest the occurrence of perennial ice lenses (GudE et al. 2003). A permafrost ice body is also suspected at Creux-du-Van, based on monitoring of electrical resistivity tomography. However, the only certain observation of permafrost is reported for Mt. Nishi-Nupukaushinupuri (Japan) by SAWADA (2008). In the lower part of this slope - in the same position as $\mathrm{BH} 2$ (Dreveneuse) - a perennial $1 \mathrm{~m}$ thick ground ice lense has been preserved for at least 3700 years. The MAAT $\left(0.7-1.7^{\circ} \mathrm{C}\right)$ is $3^{\circ} \mathrm{C}$ colder than in Dreveneuse d'en Bas. In the Bruson talus slope, where the MAGST was always lower than $0^{\circ} \mathrm{C}$ in $2005-2009$, such perennial frozen ground should therefore not be excluded.

\section{Conclusion}

It appears that advective heat fluxes («chimney effect») play a major role in the cooling of surface temperatures in porous debris accumulation. This process is very common in porous debris accumulations at low elevation in mid-latitude areas. At ground surface, a continuous succession of negative thermal anomalies is found in the lower part of a ventilated area, while in the upper part the GST regime is always positive. The coolness and stability of the GST during summer in the lower part provides favourable conditions for specific boreo-alpine ecosystems.

At depth, thin (sub)talus permafrost can form just a few metres below the surface in the lower part of the slope and can extend (and be restricted) to greater depths until the middle part of the slope. This extrazonal permafrost is mainly temperate and its geometry and occurrence can suffer very rapid changes.

The thermal balance of a ventilated talus slope is mainly conditioned by winter temperatures. The thermal conditions observed at the ground surface and in the shallow sub-surface in summertime are mainly influenced by the intensity of winter cooling and the recharge of the cold reservoir, even after the onset of a thick snowpack. Snowcover and summer temperatures thus play an insignificant role. This observation contrasts with control factors determined for «classical» permafrost terrain.

\section{References}

BÄCHLER, E. (1946): Der verwünschte oder verhexte
Wald im Brüelobel. - In: Club Nachrichten der Sektion St. Gallen SAC 18, 8: 91-96.

Bertinelli, F., Petitcolas, V., Asta J., Richard, L. \& B. Souchier (1993): Relations dynamiques entre la végétation et le sol sur éboulis froid dans les Alpes françaises méridionales. - In: Revue d'Ecologie Alpine II: 93-104.

Delaloye, R., Reynard, E., Lambiel, C., Marescot, L. \& R. Monnet (2003): Thermal anomaly in a cold scree slope (Creux-du-Van, Switzerland). - In: Phillips, M., Springman, S.M. \& L.U. Arenson (eds): Proceedings of the $8^{\text {th }}$ International Conference on Permafrost, 21 25 July 2003, Zurich: 175-180.

Delaloye, R.(2004):Contribution à l'étude du pergélisol de montagne en zone marginale. $-=$ GeoFocus 10, Fribourg: Faculté des Sciences, Université de Fribourg.

De Planhol, X. (1995): L'eau de neige. - Paris: Fayard.

De Saussure, H.-B. (1796): Voyages dans les Alpes, précédés d'un essai sur l'histoire naturelle des environs de Genève. - Tome troisième, Neuchâtel: S. Fauche.

Goering, D.J. \& P. Kumar (1996): Winter-time convection in open-graded embankments. - In: Cold Regions Science and Technology 24, 1: 57-74.

Goodrich, L.E. (1982): The influence of snow cover on the ground thermal regime. - In: Canadian Geotechnical Journal 19: 421-432.

Gorbunov, A.P., Marchenko, S.S. \& E.V. Seversky (2004): The thermal environment of blocky materials in the mountains of Central Asia. - In: Permafrost and Periglacial Processes 15, 1: 95-98.

Gude, M., Dietrich, S., Mäusbacher, R., Hauck, C., Molenda, R., Ruzicka, V. \& M. Zacharda (2003): Probable occurrence of sporadic permafrost in nonalpine scree slopes in central Europe. - In: PHILliPS, M., Springman, S.M. \& L.U. Arenson (eds): Proceedings of the $8^{\text {th }}$ International Conference on Permafrost, 21-25 July 2003, Zurich: 331-336.

Harris, S.A. \& D.E. Pedersen (1998): Thermal regimes beneath coarse blocky materials. - In: Permafrost and Periglacial Processes 9, 2: 107-120.

Hauck, C. \& C. Kneisel (2008): Quantifying the ice content in low-altitude scree slopes using geophysical methods. - In: HAuck, C. \& C. KNeISEL (eds): Applied geophysics in periglacial environments. - Cambridge: Cambridge University Press: 153-164.

Körner, C. \& G. Hoch (2006): A test of treeline theory on mountain permafrost island. - In: Arctic, Antarctic and Alpine Research 38, 1: 113-119.

LAMBIEL, C. (2006): Le pergélisol dans les terrains sédimentaires à forte déclivité: distribution, régime thermique et instabilités. - Thèse, Université de Lausanne, Institut de Géographie, coll. Travaux et Recherches 33. LEwkowicz, A.G. (2008): Evaluation of miniature temperature-loggers to monitor snowpack evolution at mountain permafrost sites, northwestern Canada. - In: Permafrost and Periglacial Processes 19, 3: 323-331. 
Lismonde, B. (2002): Climatologie du monde souterrain:Vents des ténèbres. - Grenoble:Edition du Comité Départemental de Spéléologie de Isère, Tome 1.

Luetscher, M. (2005): Processes in ice caves and their significance for paleoenvironmental reconstructions. - La Chaux-de-Fonds: Swiss Institute for Speleology and Karst Studies (SISKA).

Morard, S. \& R. Delaloye (2008): Airflow velocity measurements in ventilated porous debris accumulation. - In: $6^{\text {th }}$ Swiss Geoscience Meeting, 21-23 November 2008, Abstract volume, Lugano: 192-193.

Morard, S., Delaloye, R. \& J. Dorthe (2008a): Seasonal thermal regime of a mid-latitude ventilated debris accumulation. - In: KANE, D.L. \& K.M. HINKEL (eds): Proceedings of the $9^{\text {th }}$ International Conference on Permafrost, June 29-July 3, 2008, Fairbanks, Alaska: 1233-1238.

Morard, S., Delaloye, R. \& J. Dorthe (2008b): Indices de fonctionnement de la ventilation des éboulis. - In: RothenbüHLER, C. (ed.): Klima-Veränderungen auf der Spur. - Samedan: Academia Engiadina: 44-56. Nötzli, J. \& S. Gruber (2005): Alpiner Permafrost - ein Überblick. - In: Jahrbuch des Vereins zum Schutz der Bergwelt, München: 111-121.

Nötzli, J., Nägeli, B. \& D. Vonder Muehll (eds) (2009): Permafrost in Switzerland 2004/2005 and 2005/2006. - Glaciological Report (Permafrost) No. 6/7 of the Cryospheric Commission of the Swiss Academy of Sciences and the Department of Geography, University of Zurich.

RuZICKA, V. (1999): The freezing scree slopes and their arachnofauna. - In: MöSELER, B.M. \& R. MolenddA (eds): Lebensraum Blockhalde. Zur Ökologie periglazialer Blockhalden im ausseralpinen Mitteleuropa: Tagungsband zum Symposium vom 13. und 14. September 1997 an der Friedrich-Schiller-Universität in Jena. - Bonn: Naturhistorischer Verein: 141-147.

Sawada, Y., Ishikawa, M. \& Y. Ono (2003): Thermal regime of sporadic permafrost in a block slope on Mt. Nishi-Nupukaushinupuri, Hokkaido Island, Northern Japan. - In: Geomorphology 52,1-2: 121-130.

SAWADA, Y. (2008): Origin and age of perennial ice within a block slope in the Shikaribestu Mountains, Hokkaido, Japan. - In: KANE, D.L. \& K.M. HinKEL (eds): Proceedings of the $9^{\text {th }}$ International Conference on Permafrost, June 29-July 3, 2008, Fairbanks, Alaska: 1577-1581.

SonE, T. (2005): Extra-zonal permafrost and ground air circulation at a slope along the Kanoko-dam, Oketo town, Hokkaido, Japan. - In: Terra Nostra, $2^{\text {nd }}$ European Conference on Permafrost, 12-16 June 2005, Potsdam: 80.

Tanaka, H.L., Moon, S.-E. \& S.-J. Hwang (1999): An observational study of summertime ice formation at the Ice Valley in Milyang, Korea. - In: Science Reports of the Institute of Geoscience, University of Tsukuba, Section A, 20: 34-51.
WAKONIGG, H. (1996): Unterkühlte Schutthalden. Beiträge zur Permafrostforschung in Österreich. - In: Arbeiten aus dem Institut für Geographie, Karl-Franzens-Universität Graz 33: 209-223.

Zacharda, M., Gude, M., Kraus, S., Hauck, C., Molenda, R. \& V. Ruzicka (2005): The relict mite Rhagidia gelida (Acari, Rhagidiidae) as biological cryoindicator of periglacial microclimate in European highland screes. - In: Arctic, Antarctic and Alpine Research 37, 3: 402-408.

ZachaRda, M., Gude, M. \& V. RuZicka (2007): Thermal regime of three low elevation scree slopes in central Europe. - In: Permafrost and Periglacial Processes 18, 3:301-308.

\section{Abstract: Pluriannual thermal behaviour of low elevation cold talus slopes in western Switzerland}

The internal and reversible mechanism of air circulation (chimney effect) throughout a porous debris accumulation acts as an efficient advective conveyor of heat, which strongly influences its thermal balance during the whole year. Ground temperature monitoring carried out at eight sites located below the timberline in western Switzerland since 1997 indicates the major role played by winter air temperature conditions in the thermal regime of low elevation talus slopes and relict rock glaciers. In contrast, both snow depth and summer air temperatures have far less influence. The temperature monitoring at these sites offers the longest time series world-wide. Borehole temperature monitoring indicates the presence and growth of permafrost at one particular site from 2004-2006, with its consequent thawing again in 2007.

Keywords: low elevation cold talus slopes, air circulation, chimney effect, extrazonal permafrost, western Switzerland

\section{Résumé: Comportement thermique pluriannuel d'éboulis froids de basse altitude (Suisse occidentale)} Le mécanisme de circulation d'air par effet de cheminée dans les formations sédimentaires poreuses est un processus efficace de transfert de chaleur, influençant de manière prépondérante le bilan thermique de l'ensemble des éboulis durant l'année entière. Le suivi thermique mené sur huit éboulis situés en dessous de la limite des forêts en Suisse occidentale, depuis 1997 pour la plus longue série de mesures, a montré le rôle essentiel joué par les conditions de températures de l'air hivernales dans leur régime thermique. En revanche, l'enneigement et les températures de l'air estivales ne représentent qu'une influence secondaire. Répondant directement à des conditions météorologiques hivernales contrastées, la croissance d'un pergélisol à la base de l'éboulis a été reportée par des mesures en forage en 2004-2006, puis sa fonte dès 2007. 
Mots-clés: éboulis froids de basse altitude, circulation d'air, effet de cheminée, pergélisol extrazonal, Suisse occidentale

\section{Zusammenfassung: Mehrjähriges thermisches Ver- halten von unterkühlten Schutthalden auf niedriger Höhe (Westschweiz)}

Der Luftzirkulationsmechanismus (Kamin-Effekt) in porösen Ablagerungen ist ein effizienter Prozess der Wärmeübertragung, der die thermische Bilanz der Schutthalden während des ganzen Jahres beeinflusst. Seit 1997 wird ein thermisches Monitoring in acht Schutthalden unterhalb der Baumgrenze in der Westschweiz durchgeführt. Die Resultate zeigen, dass die Lufttemperatur im Winter die thermischen Verhältnisse in den Schutthalden massgeblich beeinflusst. Hingegen haben Schnee und Lufttemperaturen im Sommer nur einen untergeordneten Einfluss. In den Jahren 2004 bis 2006 konnte an einer bestimmten Stelle mit Hilfe von Bohrlochtemperaturmessungen sogar ein Permafrostwachstum festgestellt werden. Seit 2007 ist der Permafrost an dieser Stelle aber wieder verschwunden.
Schlüsselwörter: unterkühlte Schutthalden auf niedriger Höhe, Luftzirkulation, Kamin-Effekt, extrazonaler Permafrost, Westschweiz

Dipl.-géogr. Sébastien Morard, Prof. Dr. Reynald Delaloye, Geography Unit, Department of Geosciences, University of Fribourg, Chemin du Musée 4, CH-1700 Fribourg, Switzerland.

e-mail:

sebastien.morard@unifr.ch

reynald.delaloye@unifr.ch

Dr. Christophe Lambiel, Institute of Geography, Faculty of Geosciences and Environment, University of Lausanne, Quartier Dorigny, Bâtiment Anthropole, CH-1015 Lausanne, Switzerland.

e-mail: christophe.lambiel@unil.ch

Manuskripteingang/received/manuscrit entré le 12.1.2010

Annahme zum Druck/accepted for publication/accepté pour l'impression: 11.7.2010 